\title{
CROWS SAY CAW
}

\section{K.J. FINLEY, Box 8, Luseland, Saskatchewan. SOL 2AO}

I enjoyed Victor Friesen's attempt to re-interpret the sound of the common crow. ${ }^{2}$ To his ear it sounded like aw, rather than caw. It may be that his auditory perception is culturally biased.

A quick look at the audiospectrograph of the crow, shown in the field guide Birds of North America by Robbins, among others, reveals that the crow does in fact utter something like caw. ${ }^{3}$ The sharp onset of the audio signal is the nonstressed consonant $k$ and the subsequent inflection is the aw. Caw is not a bad catchphrase for this sound. The perceptual problem is partly a cultural one; in this case, based on the lack of "voiceless" consonants in our language and our limited alphabetic representation of such sounds. The "voiceless velar stop k," to use the jargon of language students, is a common attribute of the languages of many aboriginal peoples such as the Inuit. In this respect and others related to their language, these people may have a "better ear" for animal sounds than we do.

Several years ago, in response to reviews of bird field guide books in the Blue Jay, I commented on the value of sonagrams for birders. 'I felt that reviewers of bird field guides had overlooked or downplayed this unique feature of the Robbins' field guide. I empathized with one reviewer's point that sonagrams are "an interesting feature - for those who can read them." Although the unfamiliar format of sonagrams may be intimidating, with a little attention and practise they can extend our acoustic senses into an abstract form - like notes in sheet music. Sonagrams allow us to convert natural sounds into a two-dimensional 'format suitable for our visual senses.

Robbins' guide provides a concise introduction to the use of sonagrams and several clear examples of sounds to which we can relate. As an example, I used the sonagram of the Olive-sided Flycatcher and referred to its distinctive Whip Three Beer call. Later, I received a letter from a Blue Jay reader who said that he had never heard the $p$ sound and suggested that the call should really be Whee Three Beer. The sonagram in Robbins' guide showed that he was correct. Then I began to look for other misrepresentations. There are many; for example, there is no indication of the $Q$ in mallard's quack. But the crow definitely says caw, and in that, I feel somewhat vindicated.

1. FINLEY, K.J. 1984. Whip Three Beer. Blue Jay 42:188-189.

2. FRIESEN, V.C. 1991. Crows and their (c)awing. Blue Jay 49:123-125.

3. ROBBINS, C.S., BESTEL BRUUN and H.S. ZIM. 1966. Birds of North America. A guide to field identification. Golden Press, New York. 340 pp.

Editor's note: We could not publish the sonagrams because of coypright problems. 